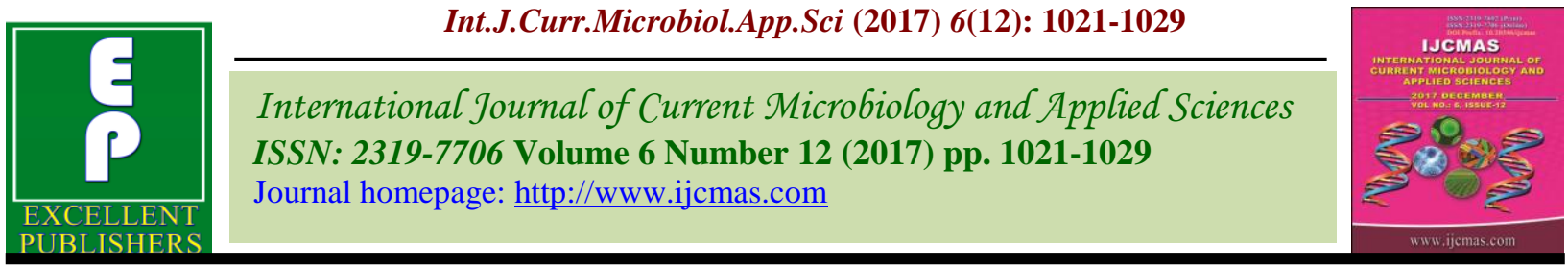

Original Research Article

https://doi.org/10.20546/ijcmas.2017.612.114

\title{
Evaluation of Field Performance and Operating Cost of Developed Potato Planter Operated with Power Tiller
}

\author{
Ashok Kumar ${ }^{*}$, Satish Kumar and Sanoj Kumar \\ Department of Agril. Engineering, BAC, Sabour, Bhagalpur, Bihar, India \\ *Corresponding author
}

A B S T R A C T

A Power tiller operated cup type potato planter was developed and field performances along with operating cost were also evaluated. Potato planter maintains a single row of spacing $620 \mathrm{~mm}$ and seed to seed distance $250 \mathrm{~mm}$. This planter singularizes the seed by a series of cups equally spaced that pass vertically through the seed box for taking one piece of seed per cup. The planter performs for mechanical functions simultaneously, viz., opening furrow, metering the seed, making ridge along with covering the seed. Four operating speeds and five seed sizes were varied to evaluate the planter. It was found that forward speed of $2.6 \mathrm{~km} / \mathrm{hr}$ is the best in respect of uniformity of spacing between tubers. Field demonstrations were conducted at college farm. The average effective field capacity of planter was $0.12 \mathrm{ha} / \mathrm{hr}$ with an average fuel consumption of $1.25 \mathrm{lit} / \mathrm{hr}$. Potato planting cost and labour requirement by cup type planter and conventional method were Rs 2270/ha, and Rs5600/ha, and 4, and 45 man-days/hr, respectively. The planter saved $61 \%$ cost and $91 \%$ labour requirement compare to conventional method. Break-even point of the potato planter was 7.6 ha. The internal rate of return of the investment of the cup type potato planter was optimum at $8 \% \mathrm{df}$, which implies that one rupees investment in potato planter would give returns on an average Rs. 4.25 annually from the date of investment until the end of planter's life. The benefit cost ratios of the investments on potato planter were found to be more than 1 which indicated that the potato planter was profitable.

\section{Introduction}

Agricultural machinery plays an important role to reduce drudgery of farm work as well as to sustain crop production at economic level. In the recent years, the number of power tillers is increasing day by day due to its versatile use in tilling, pumping, threshing, husking and transporting. Studies indicate that there is no alternate way to minimize labour shortage at peak crop season without using farm machinery. Since 1990, Farmers became more concerned with mechanical cultivation and the rates of machinery use are increasing, Animal power is slowly decreasing because of high rearing cost and lack of feed and this caused import of Chinese power tillers to fillin the gap of draft power shortage, At present more than $80 \%$ agricultural activities are carried out with power tillers (Rashid, 2007).

Potato planter improves quality of work and ensures precision placement and efficient use of costly inputs like seed, fertilizer, etc,. Potato is a highly nutritious food that provides many essential vitamins, minerals and is an important supplemental source of nutrients and calories for people living on rice- 
dominated diets. Potato excels the cereals not only in production and calories but also in quality of protein and takes much shorter time to grow, thus potato can really be the alternate tool in solving the food problem and alternate to rice particularly in developing countries like India, Agricultural operations are highly time bound and farmers prefer to do their jobs on time. Timely planting is a pre- requiremnt for good crop harvest. Potato planting operation is carried out manullay by labourers which is time consuming. Short supply of labour creates probles of timely planting. Due to delay planting, farmers could not get better yield as compared to their high investment. Maximum yield and low disease incidence were recorded in crop planter before 15 October. With delay in planting, disease incidence increased significantly resulting in maximum yield loss $(47.9 \%)$ for crop planted on $1^{\text {st }}$ december (Singh et al., 2005). Farmers are facing problem with high cultivation cost. Potato planter can help farmers to minimize the prodution cost considerably. Therefore, farmers feel justification for such a type of machine which can reduce the production cost and increase the profit. Therefore there was requirement to develop such type of planter with objectives:1) to develop a cup type potato planter attachment wuth poer tiller; 2) to evaluate performance of developed planter under different soil conditions and 3) to compare the cultivation cost with convention method.

\section{Materials and Methods}

The experiment was conducted in the Department of Agricultural Engineering, Bihar Agricultural University, Sabour, Bhagalpur, Bihar, India. The locally available variety of potato was used for this purpose. These varieties were selected because they are used by many farmers in the state and have high yielding. Two experiments were organized separately. The experiment was conducted for potato to evaluate the seed/tuber delivery of developed planters. The materials used for fabrication of planter are drills machine, Lathe machine, Grinding machine, Cutting blade, Round file, Gas welding machine, Electric welding machine, tapes, Scale, Vernier callipers, Centre punch, Hammer, Chisel, Scissors, Vice, Spanner, Screw driver, Hand grinder and Flat file.

\section{Design of cup type potato planter}

\section{Seed hopper}

The seeds container as the name implies is a device in which the seeds to be planted are kept before their gradual release into the furrowed tunnel. There was a semi conical shaped hopper fabricated for the purpose.

To ensure free flow of seeds, the slope of the hopper was fixed at $30^{\circ}$, which is modestly higher than the average angle of repose of the seeds. The material used for the design was $2 \mathrm{~mm}$ thick mild steel sheet metal. The size of the hopper was designed by following formula (Khan et al., 2015)

Volume of seed hopper $\mathrm{V}_{\mathrm{b}}=1.1 \times \mathrm{V}_{\mathrm{s}}(1)$

Where $\mathrm{V}_{\mathrm{s}}$ is the volume of seed,

$\mathrm{V}_{\mathrm{S}}=\frac{\text { Weight of seed in the box }(\mathrm{Ws})_{\mathrm{g}}}{\text { Bulk density of the seed }\left(\mathrm{T}_{\mathrm{g}}\right) \mathrm{g} / \mathrm{cm}^{\mathrm{s}}} \ldots \ldots$

\section{Seed metering device}

For the design of seed metering device the most important thing is that how many cups would be developed for desired crop; so that the spacing between the plants can be maintained. The number of cell on the seed metering device is calculated by formula (Khan et al., 2015)

$$
\mathrm{Ns}=\frac{\pi \times \mathrm{ds}}{\mathrm{N} \times \mathrm{s}}
$$


Where,

$\mathrm{D}_{\mathrm{w}}=$ diameter of drive wheel, $\mathrm{m}$

$\mathrm{N}=$ drive ratio and

$\mathrm{S}=$ plant spacing, $\mathrm{m}$

Now the second thing is that what would be the diameter of the seed metering device. So the diameter of the seed metering device is:

$$
D_{m}(\mathrm{~cm}) \frac{V_{r}}{\pi \times N_{r}}
$$

Where $\mathrm{Vr}$ is Peripheral velocity of seed metering device in $\mathrm{m} / \mathrm{min}$ and $\mathrm{Nr}$ is $\mathrm{rpm}$ of seed metering device.

Consider a specific forward speed of power tiller without any wheel slippage. Following equations are used to design the proposed potato planter (Fig. 1):

The number of potato seeds in a certain row may be calculated from equation (5)

$\mathrm{N}=\frac{\pi \mathrm{D}_{1} \mathrm{n}_{2}}{\mathrm{~d}}$

In the same time, linear distance moved by the metering disk for same number of potato seeds delivery is $(\mathrm{N} \times \mathrm{d})$

Since, $\mathrm{N} \times \mathrm{d}=\pi \mathrm{D} 2 \mathrm{n} 1$

Hence, $N=\frac{\pi D_{1} n_{2}}{d}(6)$

From equation number (5) and (6)

$\mathrm{N}=\frac{\pi \mathrm{D}_{1} \mathrm{n}_{1}}{s}=\frac{\pi \mathrm{D}_{2} \mathrm{n}_{2}}{\mathrm{~d}}$ or,$\frac{\mathrm{D}_{1}}{\mathrm{D}_{2}}=\frac{\mathrm{n}_{2}}{\mathrm{n}_{1}} \times \frac{\mathrm{s}}{\mathrm{d}}(7)$

The relationship between rotational speed and number of sprocket teeth may be obtained for power transmission mechanism through chain and sprocket from tiller wheel.

$$
\frac{\mathrm{n}_{1}}{\mathrm{n}_{2}}=\frac{\mathrm{T}_{2}}{\mathrm{~T}_{1}} \quad \text { or, } \frac{\mathrm{n}_{2}}{\mathrm{n}_{1}}=\frac{\mathrm{T}_{1}}{\mathrm{~T}_{2}}=\mathrm{k}
$$

Where, $\mathrm{k}$ is the sprocket teeth ratio between the drive wheel sprocket and metering pulley sprocket.

Again from equation number (7) and equation (8)

$\frac{D_{1}}{D_{2}}=k \times \frac{s}{d}$

Thus, the equation of required potato seed metering diameter

$D_{2}=\frac{D_{1}}{s} \times \frac{d}{k}$

Thus for known value of $\mathrm{D}_{1}, \mathrm{~S}, \mathrm{k}$ approximate of matching value for $D_{2}$ and $d$ could be selected.

Where,

$\mathrm{D}_{1}=$ Diameter of tiller drive wheel

$\mathrm{D}_{2}=$ Diameter of the metering disk

$\mathrm{T}_{1}=$ Number of teeth on drive wheel sprocket attached to the tiller

$\mathrm{T}_{2}=$ Number of teeth on metering shaft sprocket attchaed to the metering pulley

$\mathrm{N}=$ Total number of potato seed pieces planted per unit distance per unit time

$\mathrm{n}_{1}=$ Number of revolution per minuts of the power tiller drive wheel, rpm

$\mathrm{n}_{2}=$ Number of revolution per minuts of the metering pulley, rpm

$\mathrm{s}=$ required potato seed spacing in a certain row

$\mathrm{d}=$ potato sup spacing on metring disk

The main functional components of planter 
are (i) toolbar frame (ii) hitch plate (iii) potato metering derive (iv) furrow opener (vi) furrow as well as seed covering device and (vii) power transmission of the metering mechanism.

\section{Performance test of potato planter}

Performance of the potato planter was tested both on station and in the farmer's field with a view to observe the accuracy of planting. For evaluation the performance of the potato planter following data were recorded and analysed. (i) Speed of operation (ii) Uniformity index Seed spacing (iii) Theoretical field capacity Number of seed missing (iv) Effective field capacity (v) Field efficiceny (vi) Labour requirement (vii) operating cost

$\mathrm{S}=\frac{3.6 \times d}{t}(10)$

Where $\mathrm{S}$ is Travel speed $(\mathrm{km} / \mathrm{hr})$, $\mathrm{d}$ is Premeasured distance, $\mathrm{m}$ and $\mathrm{t}$ is Recorded time (sec)

\section{Seed size and forward speed}

Five different whole tuber seed sizes $(25,30$, 35,40 and $45 \mathrm{~mm}$ ) with four different forward speeds $(1.5,2.6,3.2$ and $4.2 \mathrm{~km} / \mathrm{hr})$ of power tiller were considered for the experiment of cup type potato planter. For calculating forward speed, two standing sticks fixed pre-measured distance. At the time of sowing, fixed distance passing time was recorded by stopwatch and simple calculation was done.

\section{Uniformity of spacing and uniformity index}

Uniformity of spacing is the index of planting any seeding operation. The parameters commonly used to express this uniformity are the coefficient of variance $(\mathrm{CV})$ of the spacing between successive seed pieces. The standard procedure of the International Organization for Standardization, ISO (1982) was maintained. The sample mean and sample variance of the seed spacing were taken and calculated. Generally it is expressed as percentage. The following are the equation of uniformity calculation (Hossain et al., 2015):

$\mathrm{CV}=\frac{\sqrt{\mathrm{V}_{\mathrm{x}}}}{\mathrm{x}} \times 100$

Where, $\mathrm{CV}=$ coefficient of variation, $\% ; \mathrm{x}=$ mean value of sample, $\mathrm{mm} ; \mathrm{v}_{\mathrm{x}}=$ variance of sample seed spacing, $\mathrm{mm}$

Uniformity index $=\left(1-\frac{\sqrt{V_{x}}}{x}\right) \times 100$

\section{Theoretical field capacity}

Theoretical field capacity was calculated as follows (Meri et al., 2002).

$\mathrm{TFC}=\frac{\mathrm{W} \times \mathrm{S}}{10}(13)$

Where TFC is Theoretical field capacity (ha/hr), W = Width of the seeder $(\mathrm{m})$ and $\mathrm{S}$ is Travel speed $(\mathrm{km} / \mathrm{hr})$

\section{Effective field capacity}

The effective field capacity of the potato planter is a function of the rated width of the planter, the percentage of the rated width actually utilized, the speed of travel, and the amount of field time lost during the operation. It is the actual average rate of coverage by the planter. Effective field capacity is usually expressed as hectare per hour. It is calculated by following formula (Kepner et al., 1978):

$\mathrm{EFC}=\frac{\mathrm{A}}{\mathrm{T}}(14)$

Where, $\mathrm{EFC}=$ effective field capacity (ha/hr), $\mathrm{A}=$ actual filed coverage (ha) and $\mathrm{T}=$ Total time of planting (hr) 


\section{Field efficiency}

It is the percentage of the ratio of effective field capacity and theoretical field capacity (Kepner et al., 1978).

$F_{e}=\frac{\text { EFC }}{T F C}(15)$

Where,

$\mathrm{Fe}=$ Field efficiency $(\%)$

\section{Cost calculation}

Cost calculation was done on the basis of fixed cost and variable cost of the potato planter. The related cost parameters were as follows: (i) Purchase price of potato planter (ii) Depreciation (iii) Salvage value of the planter (iv) Planter life year (v) Bank interest, $\%$ (vi) operating cost, Rs/day (vi) Fuel consumption, lit/h (vii) Lubrication cost (viii) Repair and maintenance cost and (ix) Power Tiller hire price for planter operation.

Cost of conventional planting method was also recorded for cost comparison with mechanical planting. Thus, the total cost of planting was the sum of fixed cost and variable cost of the planter (Hunt, 1995).

\section{Cost benefit analysis}

Cost benefit analysis was taken into consideration for evaluation of the power tiller operated potato planter utilization in the farmer's field. The discount measures commonly used in agricultural projects: Benefit cost ratio (BCR), net present value (NPV), and internal rate of return (IRR) were used to measure the economic viability of the average earning power of an investment over the total life. In other word, IRR is the discount rate that makes NPV equal to zero. This shows maximum possible return on investment of the potato planter. The BCR,
NPV and IRR are calculated as per following formula (Hossain et al., 2015):

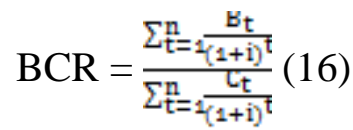

$$
\begin{aligned}
& \mathrm{NPV}=\sum_{\mathrm{t}=1}^{\mathrm{n}} \frac{\mathrm{B}_{\mathrm{t}}-\mathrm{C}_{\mathrm{t}}}{(1+\mathrm{i})^{\mathrm{t}}}(17)
\end{aligned}
$$

$\mathrm{IRR}=$ Lower discount rate+ difference between discount rates

$\mathrm{X}=\frac{\text { NPV at lower discount rate }}{\text { Sum of two NPV ignoring sign }}$

IRR is that discounted rate 'I' such that

$\sum_{t=1}^{n} \frac{B_{t}-C_{t}}{(1+1)^{t}}=0$

Where, $\mathrm{B}_{\mathrm{t}}=$ benefit in year $\mathrm{t}$; $\mathrm{C}_{\mathrm{t}}=$ cost in year $\mathrm{t} ; \mathrm{t}=1,2,3 \ldots \ldots \ldots \mathrm{n}$ and $\mathrm{n}=$ number of years $\mathrm{i}=$ interest (discount) rate, \%

\section{Break even use}

The break even use (BEU) can be determined by the following equation:

$\mathrm{BEU}=\frac{\mathrm{AC}}{\mathrm{CR}-\mathrm{VC}}$

Where,

$\mathrm{BEU}=\mathrm{Break}$ even use (ha/yr)

$\mathrm{AC}=$ Annual ownership costs $(\mathrm{Rs} / \mathrm{Yr})$

$\mathrm{CR}=$ Custom hire rate $(\mathrm{Rs} / \mathrm{ha})$

\section{Results and Discussion}

\section{Development of potato planter}

All the parts of the planter were fabricated from mild steel material, the seed funnel which was made from rubber material, and the tuber tube which was also made from rubber material. The choice of material for the 
seed funnel and seed tube was used because the coefficient of restitution for plastic material is lower than that of a mild steel sheet of the same thickness. The opted material will go a long way in minimizing seed bouncing, thereby protecting the seeds from damage due to impact. The hopper was fabricated using $2 \mathrm{~mm}$ thick mild steel metal sheet having capacity of $10 \mathrm{~kg}$. The metering mechanism was fabricated from good quality wood and metal sheet. It was observed that the number of teeth in small gear sprocket and large gear sprocket was 15 and 37 respectively.

The main frame which supports every other component of the planter was fabricated using mild steel flat bar of length of $750 \mathrm{~mm}$ and width of $450 \mathrm{~mm}$. The adjustable furrow opener and furrow closer were both fabricated using $\mathrm{M} S$ flat bar and MS metal sheet respectively.

Lever type gear arrangement was provided for easy lifting of furrow closer discs when not in operation of while travelling on road (Fig. 1). The planter's transport wheels were fabricated using a $25 \mathrm{~mm}$ MS metal sheet and 17 lugs were welded on periphery of transport wheel to provide additional friction during operation.

Fabrication with appropriate dimension of the potato planter components were carried out according to the designed equation (5) (Table $1)$. Potato planter was shown in figure 1 . There were 13 pairs of potato cups fixed on a $40 \mathrm{~mm}$ flat belt, forming an endless loop. The cup size is $40 \mathrm{~mm}$. According to the design criteria, potato cups were positioned $110 \mathrm{~mm}$ apart from each successive cup to provide he recommended $250 \mathrm{~mm}$ spacing for planting whole potato seeds. The belt was coupled between drive and driven pulleys $780 \mathrm{~mm}$ distance vertically arranged on the toolbar frame. The diameter of the seed metering device pulley was $120 \mathrm{~mm}$. the sprocket ratio was 2.2 for obtaining desired seed spacing $250 \mathrm{~mm}$. In the forward speed of potato planter without drive wheel slippage metering cup hold one piece seed and release it near the bottom of the open furrow.

The spacing between one seed to another seed was controlled by the metering pulley rotation through sprocket ratio and power transmission arrangement. For satisfactory planting operation, $3.5 \mathrm{~kg}$ graded potato seed needs to be deposited in the secondary seed box. The planter regulates seeds automatically. Main operator can perform planting operation alone.

\section{Effect of forward speed and seed size on uniformity index}

Uniformity of spacing was evaluated for potato planter with different seed sizes (25, $30,35,40$ and $45 \mathrm{~mm}$ ). Uniformity of spacing varied with the increase of operational speed (Fig. 3). Uniformity index of seed distribution decreased with the increased of forward speed of potato planter. Among the five seed sizes, it was observed that the $35 \mathrm{~mm}$ size showed higher uniformity index than that of 25,30 , 35, 40 and $45 \mathrm{~mm}$ size. The seed size $45 \mathrm{~mm}$ produced the lowest uniformity index.

There were significant variations of uniformity index among the seed sizes. At higher speed, cup could not pick seed pieces properly. The cause of this variation was due to missing seeds into the cups during the planting operations. Different seed sizes exerted different loads on the metering cups of belt during the belt movement through the secondary seed box. So, operational seed should be selected carefully for more planting accuracy. Similar results were obtained by Khan et al., (2015) for single row multi-crop planter and Hossain et al., (2009) for potato planter. 
Fig.1 Planter attached with power tiller

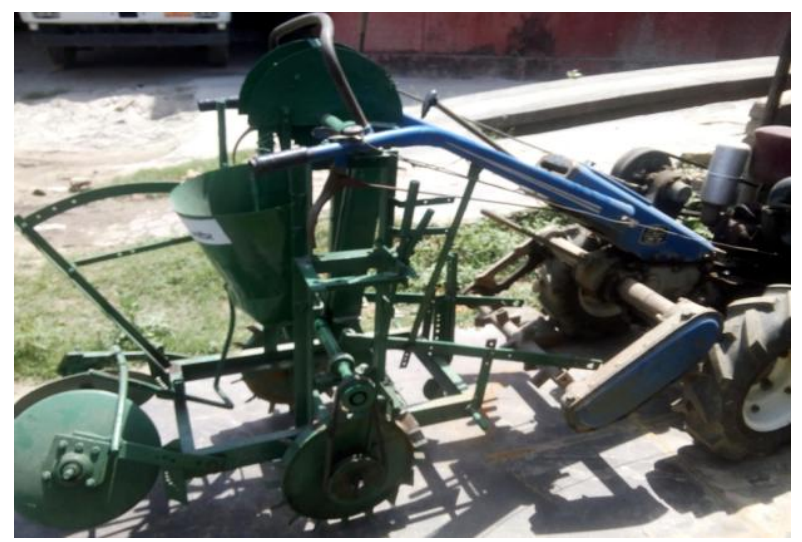

Fig.3 Effect of forward speed on missing seed by planter

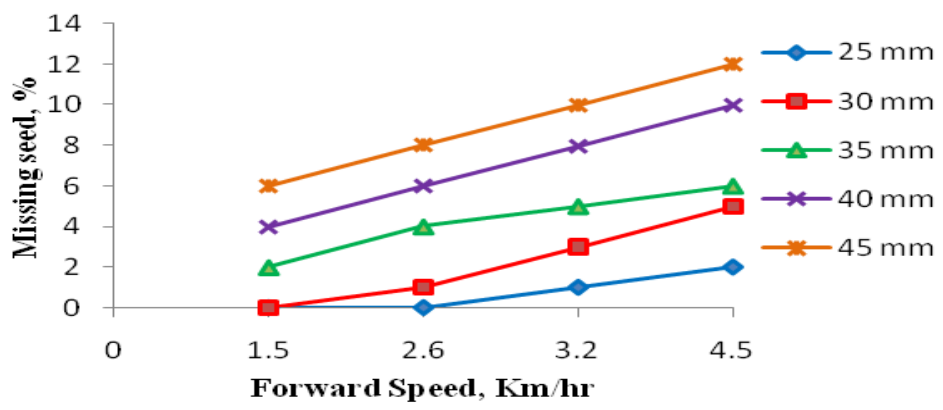

Fig.2 Covering of seeds with bund former

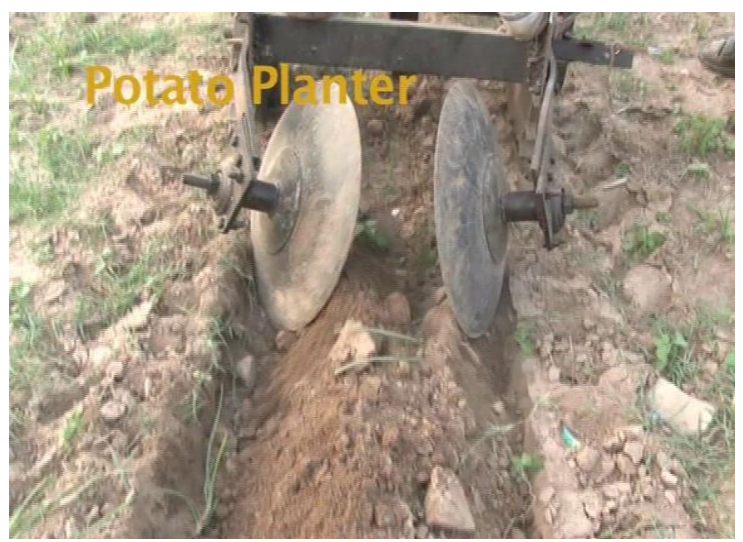

Fig.4 Uniformity index of seed placement on forward speed and seed size by planter

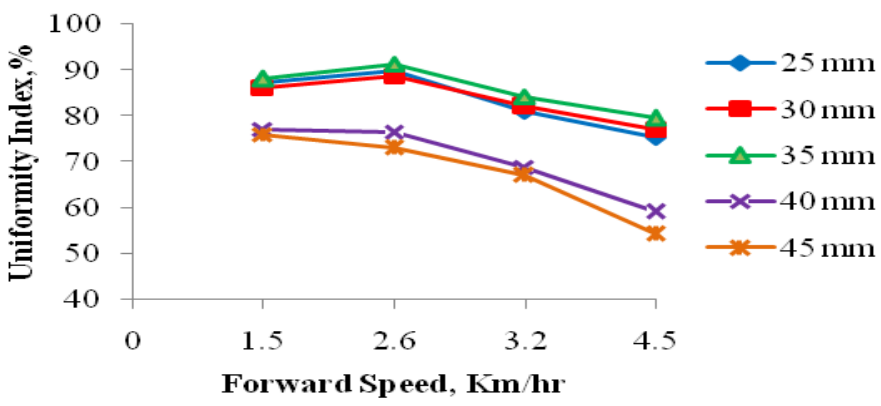

Table.1 Specification of developed potato planter

\begin{tabular}{|l|c|l|l|}
\hline Particulars & No. of Items & \multicolumn{1}{|c|}{ Dimension (mm) } & \multicolumn{1}{|c|}{ Fabricated Material } \\
\hline Frame & 1 & $750 \times 450$ & M.S.Flat bar \\
\hline Hopper & 2 & $\begin{array}{l}\mathrm{H}_{\mathrm{p}}: 430 \times 330 \times 70 \\
\mathrm{H}_{\mathrm{m}}: 290 \times 160 \times 90\end{array}$ & M.S.Sheet metal \\
\hline Seed metering & 2 & Cup type & Medium carbon steel and carbon \\
\hline Transport wheel & 2 & Dia-350 each & M.S. Sheet metal \\
\hline Lugs & 17 & $50 \times 40$ each & M.S. Sheet metal \\
\hline Distance between transport wheels & 1 & Dia -570 & M.S. Sheet metal \\
\hline Teeth in small gear sprocket & 15 & Dia -60 & M.S. Sheet metal \\
\hline Teeth large gear sprocket & 37 & Dia -180 & M.S. Sheet metal \\
\hline Bund former disc & 02 & Dia -350 each & M.S. Sheet metal \\
\hline Shaft & 2 & Dia -30 each & Medium carbon steel \\
\hline Cups & 24 & Dia -60 each & Metal wire \\
\hline Spacing between cups & - & 80 & Metal wire \\
\hline Seed tube & 1 & Length-650, Dia-30 & Plastic \\
\hline Blocks & 8 & Dia -60 each & Bronze \\
\hline Pintel chain & 1 & No of links-100 & Malleable links \\
\hline Furrow opener & 1 & L=100, W=90 & M.S. Flat bar \\
\hline No. o pulley & 03 & Dia -160, Dia -80, Dia $_{2}-80$ & M.S. Sheet \\
\hline
\end{tabular}


Table.2 Field performance of the potato planter

\begin{tabular}{|l|c|}
\hline Parameters of potato planter & Observed data \\
\hline Average forward speed, $\mathrm{km} / \mathrm{hr}$ & 2.6 \\
\hline Width of planter, mm & 620 \\
\hline Theoretical field capacity, ha/hr & 0.14 \\
\hline Effective field capacity, ha/hr & 0.12 \\
\hline Field efficiency, \% & 81.6 \\
\hline Average fuel consumption, lit/hr & 1.25 \\
\hline
\end{tabular}

Effect of seed size and forward speed on missing seed

The missing seed percentage varied depending on seed sizes and different forward speeds of operation. In cup type potato planter, missing seed percentage were found more with the larger potato seeds compare to smaller seed size (Fig. 4). The missing seed percentages were found to be increased with the increasing rate for the increase of forward speed for any seed size. The increasing rate was lower in first three speeds for all the seed sizes but it drastically increased with the higher operational speed. At slower speeds, potato seeds had more time to be held properly in the cup space one after another in the vertically moving cup. At the faster operating speeds, potato seeds had less time for being caused by the cups. Thus, there was more possibility to have missing seed or skips. This result is in line with results of Khan et al., (2015) for single row multi-crop planter and Hossain et al., (2009) for potato planter.

\section{Field performance of the potato planter}

Potato planter adaptive trial was conducted at different locations of BAC farm of Bihar Agricultural University, Sabour in the district of Bhagalpur state of Bihar, India. In these trials, the potato planter field performances were evaluated on the basis of uniformity of spacing, planting cost and benefit, Potato planter, planting view in the farmers filed. In these trials average seed size of $35 \mathrm{~mm}$ used for cup type planter with operating speed of $2.6 \mathrm{~km} / \mathrm{hr}$. Cup type planter can form bed of $620 \mathrm{~mm}$ size per pass. Field performance of power tiller operated potato planter were calculated on the basis of areas coverage, opening speed, effective time coverage, width of planting and fuel consumption. From table 2 it was found that the effective filed capacity and filed efficiency of developed planter was $0.12 \mathrm{ha} / \mathrm{hr}$ and $81.6 \%$ respectively. Also it was observed that average fuel consumption of the potato planter was 1.25 $\mathrm{lit} / \mathrm{hr}$. It was also found that EFC varied on field size and shape. EFC was more in large filed size compare to small field size and irregular shape of field. EFC and field efficiency can be increased through operator intensive training on machinery management which improves skills. These results were in agreement with those reported in some previous studies (Aikins et al., 2010). It was found that cos of operation was Rs. 2270/ha. On the other hand using whole tuber and cut piece seed, manually potato planting cost was Rs. 5200/ha and Rs.6500/ha. Labour requirement for whole tuber seed planting in case of planter and conventional method were 4 man days and 45 man days, respectively. Potato planter can save labour requirement of 36 man days/ha and planting cost Rs 2930/ha which was equivalent to $91 \%$ and $61 \%$ saving of labour and cost, respectively compare to conventional potato planting method.

Break-even used (BEU) of power tiller operated potato planter was calculated on the basis yearly land use and custom hire rate of potato planter. It was observed that cost of potato planting per hectare decreases with the increase of yearly land area use. Presently custom hiring rate of the potato planter in the field is Rs 4500/ha. Break-even use of the planter was calculated as 
7.8 ha. This BEU indicated that machine owner must plant 7.8 ha land for his yearly no loss margin. A potato planter owner or an operator should make a target maximum area for a year to pay back the investment.

The NPVs of the investment were estimated for the planter for 10 years life. On the other hand using the base parameters, the IRR of the investment on the cup type potato was estimated to be minimum, which implies that one rupee invested in potato planter gives return on an average Rs 4.25 annually from the date of investment until the end planter life. It was also found that BCRs of the investments were found to be more than 1 which indicated that the potato planter was profitable. This result is in line with results of Khan et al., (2015) for single row multi-crop planter and Hossain et al., (2009) for potato planter.

This work focused on development, performance and operating cost of planter operated with power tiller. The developed planter is cheap, easily affordable, easy to maintain and less laborious to use. The depth of seed in the secondary chamber should be maintained at constant level so that all cups receive seed piece effectively. The picking chamber should be approximately two thirds full for better performance. The planter performs satisfactorily at the operating speed of 2.6-3.2 $\mathrm{km} / \mathrm{h}$ with seed size $30-35 \mathrm{~mm}$. Labour requirement for plantation by using a potato planter and conventional method was 4 man day/ha and 45 man days/ha respectively. BCR of the investment of potato planter was found to be more than 1 which indicated that the potato planter is profitable. The planter will go a long way in making farming more attractive and increasing productivity. This machine will be widely accepted by the small and marginal Indian farmers.

\section{References}

Aikins, SHM, Bart, P.A. and Opoku, B.S. 2010. Performance Evaluation of Jab Planters For Maize Planting And Inorganic Fertilizer Application. ARPN Journal of Agricultural and Biological Science. 5(1): 29-33.

Hossain, M.D., Hossain, M.M., Zinuddin, A.T.M., Meisner, C.A, and Ahmmed, S. 2009. Design and development of power tiller operated cup type potato planter. Journal of Agricultural Engineering, The Institute of Engineers, Bangladesh. Vol.37/AE, December 2009.

Hunt, D. 1995. Farm Power and Machinery Management. Cost determination. $9^{\text {th }}$ Edition lowa state University press. America.

Kepner, R.A., Bainer, R. and Barger, E.L.1978. Principles of farm machinery. 3rd Edition. West port. G; AVI publishing company Inc.

Khan, K., Moses, S. C. and Kumar, A. 2015. The Design and Fabrication of a Manually Operated Single Row MultiCrops Planter. IOSR Journal of Agriculture and Veterinary Science. 8 (10): 147-158.

Mari, G.R., Menon, S.A., Leghari, N. and Brohi, A.D. 2002. Evaluation of Tractor Operated Potato Planter. Pakistan Journal of Applied Science. 2(9):889-891.

Rashid, M.H. 2007. Status of Agricultural Engineering research and development in Bangladesh. Bangladesh country paper. http://www.unapcaem.org/Activities\%20 Files/A0704/PPT11.pdf. The paper was downloaded on 18 September, 2017.

Singh, B., Lakra, B.S., Ram, N. and Mahender, S, 2005. Effect of planting time on black surf development in potato. Animals of Biology, 21(2):245-248.

\section{How to cite this article:}

Ashok Kumar, Satish Kumar and Sanoj Kumar. 2017. Evaluation of Field Performance and Operating Cost of Developed Potato Planter Operated with Power Tiller. Int.J.Curr.Microbiol.App.Sci. 6(12): 1021-1029. doi: https://doi.org/10.20546/ijcmas.2017.612.114 